\title{
THE EFFECT OF pH ON SYNTHESIS OF HYDROXYAPATITE FROM GELOINA COAXANS SHELL
}

\author{
Pepi Helza Yanti*1, Nia $^{1}$ \\ ${ }^{1}$ Department of Chemistry-FMIPA-Universitas Riau \\ Kampus Bina Widya Jl. HR. Soebrantas 12,5 KM Panam, Pekanbaru, Indonesia \\ peppyhelza@yahoo.com
}

\begin{abstract}
The effect of $\mathrm{pH}$ on synthesis of hydroxyapatite from Geloina coaxans shell has been done by precipitation method. Geloina coaxans shells and several phosphate sources $\left(\mathrm{NH}_{4}\right)_{2} \mathrm{HPO}_{4}$ and $\mathrm{H}_{3} \mathrm{PO}_{4}$ were used as precursors on synthesis of HAp. Synthesis of HAp was done with molar ratio of precursors 1,67 and $\mathrm{pH}$ of solution were varied at $10,12,13$, and 14 . The result proved that nano-HAp can be obtained successfully and shown that $\mathrm{pH}$ value was a significant parameter variable on synthesis HAp that can influence crystalinity and purity of HAp. Using Schererr equation, particle size of $\mathrm{HAp}$ powder of $\left(\mathrm{NH}_{4}\right)_{2} \mathrm{HPO}_{4}$ was 26,69 while $\mathrm{H}_{3} \mathrm{PO}_{4}$ was $40 \mathrm{~nm}$ respectively.
\end{abstract}

Keywords: Geloina coaxans, $\mathrm{HAp},\left(\mathrm{NH}_{4}\right)_{2} \mathrm{HPO}_{4}$ and $\mathrm{H}_{3} \mathrm{PO}_{4}$

\section{ABSTRAK}

Pengaruh pH pada sintesis hidroksiapatit mengggunakan cangkang lokan (Geloina coaxans) telah dilakukan menggunakan metode pengendapan. Cangkang lokan (Geloina coaxans) dan beberapa sumber posfat seperti $\left(\mathrm{NH}_{4}\right)_{2} \mathrm{HPO}_{4}$ dan $\mathrm{H}_{3} \mathrm{PO}_{4}$ telah digunakan sebagai prekursor pada sintesis senyawa hidroksiapatit. Sintesis senyawa hidroksiapatit ini dilakukan dengan perbandingan molar prekursor 1,67 dan $\mathrm{pH}$ larutan divariasikan pada 10, 12, 13, dan 14. Hasil yang diperoleh menunjukkan bahwa nano-hidroksiapatit dapat diperoleh melalui variasi $\mathrm{pH}$, dan membuktikan bahwa $\mathrm{pH}$ merupakan suatu parameter penting dalam sintesis hidroksiapatit yang dapat mempengaruhi kristalinitas dan kemurnian dari hidroksiapatit yang dihasilkan. Dengan menggunakan persamaan Schererr, ukuran partikel hidroksiapatit yang yang dihasilkan $\left(\mathrm{NH}_{4}\right)_{2} \mathrm{HPO}_{4}$ adalah 26,69 sedangkan $\mathrm{H}_{3} \mathrm{PO}_{4}$ adalah $40 \mathrm{~nm}$

Kata kunci: Geloina coaxans, $\mathrm{HAp},\left(\mathrm{NH}_{4}\right)_{2} \mathrm{HPO}_{4}$ and $\mathrm{H}_{3} \mathrm{PO}_{4}$

\section{INTRODUCTION}

Hydroxyapatite $\mathrm{Ca}_{10}\left(\mathrm{PO}_{4}\right)_{6}(\mathrm{OH})_{2}$ or HAp is the main mineral constituent of teeth and vertebrate bones. It has been well proved and documented that HAp nanoparticles can significantly increase the biocompatibility and bioactivity of biomaterials. There are many type of $\mathrm{Ca} / \mathrm{P}$ salts, such as single, polycrystaline and composite. The phases used depend on the properties and function required. Several factors such as parameter reaction, source or type of precursors and method of preparation have been developed to synthesis HAp.

HAp have many applications that caused many reasons to synthesis this material. By synthesis of HAp the mechanical properties, particle or crystal size and morphology of HAp can be controlled. HAp can be used as a adorbent of dyes [1] and heavy metals [2], catalyst for chemical reactions such as the Michael-type addition and methane oxidation [3], [4] and biosensor [5]. The several research also has been done to fabrication of HAp such as hydrothermal [6], microwave [7] and precipitation [8]. 
Source and type of precursors of $\mathrm{Ca} / \mathrm{P}$ also influence HAp synthesized. Geloina coaxans shell was a potential material that can be used as calsium (Ca) source because have high carbonate composition. This carbonate can be decomposed by calcination to produce calcium oxide as precursor Ca on synthesis HAp. The usage of Geloina coaxans shell as precursor from natural sources is inexpensive and uncomplicated. The previous research revelaed HAp can be produced by using Mussel shell [7] and Oyster shell [8].

This article is focused to learn the effect of $\mathrm{pH}$ on synthesis of hydroxyapatite from Geloina coaxans shell that was synthesized by wet method. $\mathrm{pH}$ is important factor that can influence HAp synthesized. This parameter was done to analyze the influence condition of solution on synthesis HAp. The analysis of product was done by XRD instrument to identification the calcium phosphate salts obtained. Synthesis of HAp will be done with molar ratio of precursor 1,67 and $\mathrm{pH}$ of solution was varied at 10,12,13 and 14 .

\section{EXPERIMENTAL SECTION}

\subsection{Materials}

The materials, which were used in this research, Geloina coaxans shell (Rokan Hilir-Riau Province), diammonium hydrophosphate $\left(\mathrm{NH}_{4}\right)_{2} \mathrm{HPO}_{4}$ (merck), $\mathrm{H}_{3} \mathrm{PO}_{4}$ (merck), $\mathrm{NH}_{4} \mathrm{OH}$ 0,1 $\mathrm{M}$ and aquabidest.

\subsection{Instrumentation}

The equipments which were used: glass equipments, blender (Philips), furnace (vulcan ${ }^{\mathrm{TM}}$ seri A 130), digital pH, oven (Gallen kemp), hotplate (Rexim RSH-1DR as One), analytical balance (Mettler AE 200) sieve-200 mesh, crucible, (W.S Tyler Incorporated U.S.A), vacum, whatman 42, aluminum foil, X-Ray Flourocence (S2 Ranger Burker), X-Ray Diffraction (Gbc Emm).

\subsection{PROCEDURE}

Preparation of Geloina coaxans as precursor $\mathrm{Ca}$

Geloina coaxans shell (sample) was collected and washed for removing its inner membrane. After that, sample was dried out and mashed. The particle size of sample was adjusted 200 mesh. The powder obtained was analyzed by X-Ray Flouresence technique to determinate the chemical composition of Geloina coaxans shell. The Geloina coaxans shell was decomposed by calcination using furnace to remove organic composition and decompose calcium carbonate into calcium oxide at $900^{\circ} \mathrm{C}$ for 12 hours.

Synthesis of Hydroxyapatite (HAp)

Hydroxyapatite was synthesized by precipitation method with molar ratio of precursor $(\mathrm{Ca} / \mathrm{P})=1,67$. $\mathrm{CaO}$ was diluted with aquabidest. The $\mathrm{Ca}(\mathrm{OH})_{2}$ solution was vigorously stired in $250 \mathrm{ml}$ beaker glass at room temperature and $100 \mathrm{ml}$ of dyamonium hydrogenphospate was added drop-wise, and then stirring at $300 \mathrm{rpm}$. The $\mathrm{pH}$ of system was varied at 10,12, 13 and 14 throughout the strirring process by using $0,1 \mathrm{M} \mathrm{NH}_{4} \mathrm{OH}$ solution. The solution was overnight, then a white precipitate was formed. This product was vacum dried and calcinated at $900^{\circ} \mathrm{C}$ for 2 hours. The synthesized powder was used for further characterization.

\subsection{Characterization}

The prepared HAp were characterized by X-Ray Flouresence and X-Ray Diffractrometer (XRD) techniques.

\section{RESULTS AND DISCUSSION}

\subsection{The chemical composition analysis of Geloina coaxans.}

The chemical composition of Geloina coaxans was analyzed by X-Ray Flouresence (XRF) technique. The obtained results show that the main composition of Geloina coaxans was $\mathrm{CaO}$ and several oxides such as $\mathrm{Na}_{2} \mathrm{O} ; \mathrm{MgO} ; \mathrm{SiO}_{2} ; \mathrm{Al}_{2} \mathrm{O}_{3} ; \mathrm{SO}_{3}$ and $\mathrm{K}_{2} \mathrm{O}$ of trivial amount. Chemical composition of Geloina coaxans can be seen on Table 1 below. 
Table 1 The chemical composition analysis of Geloina coaxans by XRF technique

\begin{tabular}{ll}
\hline Chemical composition & $\%$ \\
\hline $\mathbf{C a O}$ & $\mathbf{8 6 , 0 1}$ \\
$\mathrm{Na}_{2} \mathrm{O}$ & 8,19 \\
$\mathrm{MgO}$ & 1,73 \\
$\mathrm{SiO}_{2}$ & 0,73 \\
$\mathrm{Al}_{2} \mathrm{O}_{3}$ & 0,60 \\
$\mathrm{SO}_{3}$ & 0,58 \\
$\mathrm{~K}_{2} \mathrm{O}$ & 0,57 \\
\hline
\end{tabular}

3.2. The phase minerals analysis of Geloina coaxans calcinated at $900^{\circ} \mathrm{C}$ for 12 hours.

Calcination were done to learn the decomposition calcium carbonate to calcium oxides. Analysis was used by X-Ray Diffraction (XRD) to determine the minerals phase and crystalinity of Geloina coaxans after calcination at $900^{\circ} \mathrm{C}$ for 12 hours. In Figure 1, the result of phase mineral analysis is shown.

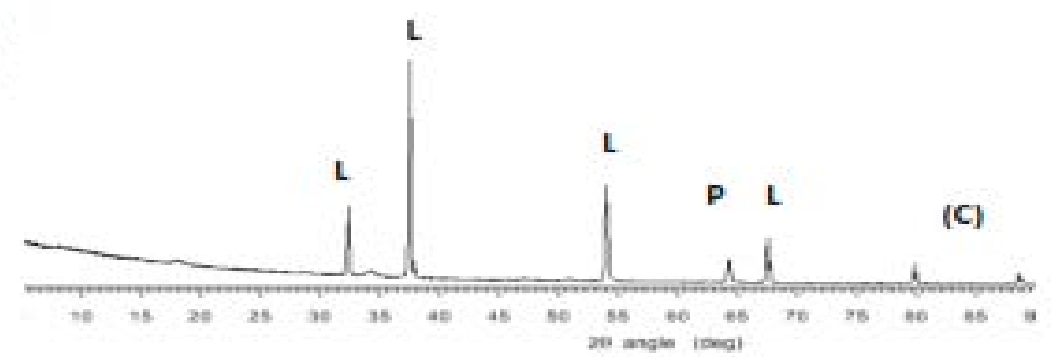

Figure 1 XRD Patterns of calcination time at $900^{\circ} \mathrm{C}$ for 12 hours (c=calcinated)

$$
\left[P=\text { Porlandite }\left[\mathrm{Ca}(\mathrm{OH})_{2}\right] ; \mathrm{L}=\text { Lime }(\mathrm{CaO})\right.
$$

The XRD patterns showed the of type minerals of Geloina coaxans and revealed that Geloina coaxans consist of lime and portlandite minerals. The obtained powder was compared with JCPDS (Joint committee powder Diffraction Standar) (No 48-1467) and (No 44-1481). The specific peak of $\mathrm{CaO}$ obtained at $900^{\circ} \mathrm{C}$ for 12 hours at $2 \theta=45,0^{0} ; 32.3^{0} ; 67.4^{0} ; 37,3^{0}$ and this $\mathrm{CaO}$ was used as calcium source on synthesis hydroxyapatite. Portlandite minerals also appeared at $2 \theta=64,2$ and 34,17 . The molusca shell decomposed to oxide at $754^{\circ} \mathrm{C}$ and perfect decomposed at 880 for 4 hours [9]. The differences calcination time of carbonate depent on the source of carbonate

\subsection{Analysis of HAp synthesized by X-Ray Diffraction}

The powder of HAp synthesized using precipitation method was analyzed by XRD instrument. XRD analysis was done to determinate mineral phase and crystalinity of prepared HAp nano-crystalline. In Figure 2 and Figure 3, the result of hydroxyapatite is shown. 


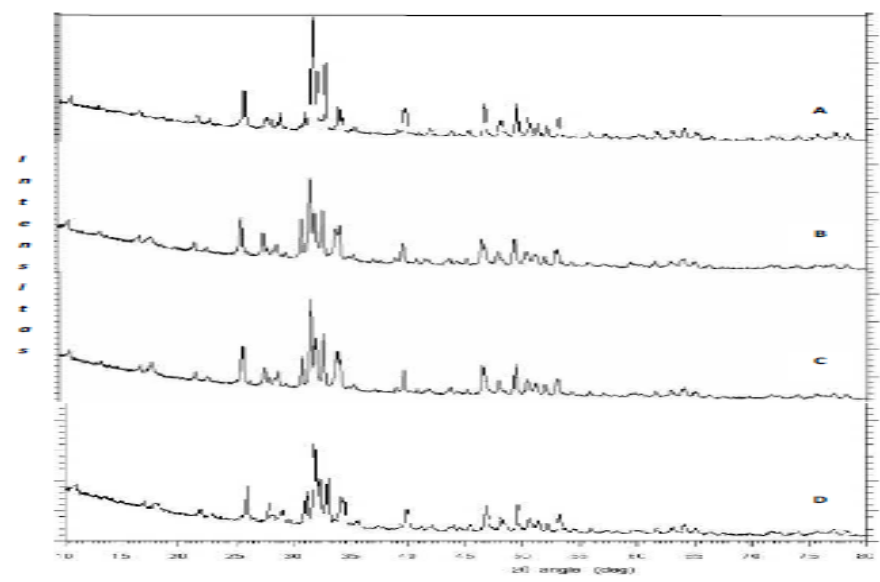

Figure 2 XRD Patterns of HAp powder synthesized at different pH (A=10; $B=12 ; C=13$; dan $D=14)$ using $\left(\mathrm{NH}_{4}\right) 2$ $\mathrm{HPO}_{4}$ as precursor

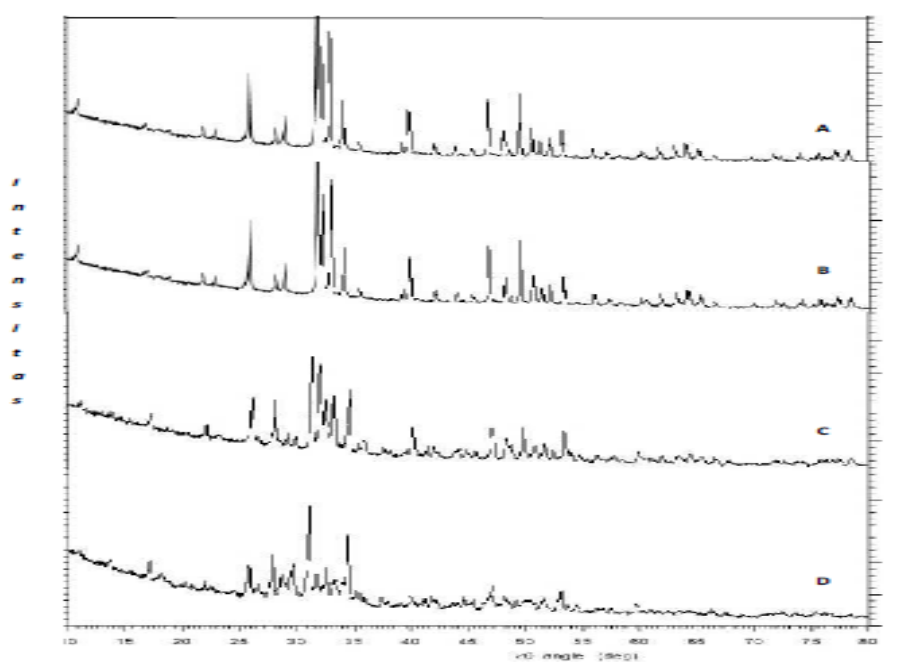

Figure 3 XRD Patterns of HAp powder synthesized at different $\mathrm{pH}$ at $(\mathrm{A}=10 ; \mathrm{B}=12 ; \mathrm{C}=13$; dan $\mathrm{D}=14)$ using $\mathrm{H}_{3} \mathrm{PO}_{4}$ as precursor

$$
\begin{aligned}
& \mathrm{CaO}+\mathrm{H}_{2} \mathrm{O} \longrightarrow \mathrm{Ca}(\mathrm{OH})_{2} \\
& 10 \mathrm{Ca}(\mathrm{OH})_{2}+6\left(\mathrm{NH}_{4}\right)_{2} \mathrm{HPO}_{4} \longrightarrow \mathrm{Ca}_{10}\left(\mathrm{PO}_{4}\right)_{6}(\mathrm{OH})_{2}+12 \mathrm{NH}_{3}+18 \mathrm{H}_{2} \mathrm{O}
\end{aligned}
$$

Analysis was done by X-Ray Diffraction (XRD) to determine the minerals phase and crystalinity of HAp at different $\mathrm{pH}$. The several parameters have been done to learn crystalinity and purity of HAp obtained. $\mathrm{pH}$ is important factor that can influence HAp synthesized. This parameter was done to analyze the influence condition of solution on synthesis HAp

A specific peak of HAp or hydroxyapatite was observed in the syntesized sample. In the Figure 2. the specific peak of HAp appeared at severals $\mathrm{pH}$ but $\mathrm{pH}$ was 13 show HAp synthesized has good crystalinity than others, this result indicate that a better crystalization has been formed. The peaks of HAp can be seen at $2 \theta=31,7^{\circ}$ and $2 \theta=25,9^{\circ}$ (JCPDS No 09-0432. However $\mathrm{pH}$ can influence crystalinity and purity of HAp obtained and types of calcium salts produced. The crystallite size of HAp nanoparticles was determined using the Scherrer equation 


$$
\mathrm{D}=\frac{\mathrm{K} \lambda}{\beta \cos \theta}
$$

Where $\mathrm{D}$ is the average of crystallite size, $\beta$ the coreected full width of the peak at half of the maximum intensity, FWHM (in radians), $\lambda=$ the wave length of X-Ray radiation $(0,154060 \mathrm{~nm})$ and $\mathrm{K}=$ contant related to crystallite shape

Crystal size of HAp synthesized at $\mathrm{pH}$ was 14 examined with Scherrer equation above, and obtained crystal size of HAp was 26,69 nm while Guo et al (2013) using $\left(\mathrm{NH}_{4}\right)_{2} \mathrm{HPO}$ and calcium nitrate produced particle size of HAp were 11,49 and $249 \mathrm{~nm}$ for calcination time $450^{\circ}, 750^{\circ} \mathrm{C}$ and $900^{\circ} \mathrm{C}$ respectively. Whereas in Figure 3 by using $\mathrm{H}_{3} \mathrm{PO}_{4}$ as precursor $\mathrm{pH}$ was 10 showed the better crystanity than other $\mathrm{pH}$, and crystal size of HAp synthesized was $40 \mathrm{~nm}$. the peaks of Hap appeared at $2 \theta=31,7^{\circ}$ and $2 \theta=46,8^{\circ}$. Abidi et al (2013) using $\mathrm{H}_{3} \mathrm{PO}_{4}$ produced crystal size of HAp about 8.47-24.47 nm.

The previous research explained that variation of $\mathrm{pH}$ at 5,6,9, and 11 proved that at $\mathrm{pH} 11$ was stable condition to synthesis Hap if compared with other $\mathrm{pH}$ [10] while other research learned that suitable $\mathrm{pH}$ was a crucial factor on synthesis HAp [11], also revealed that nano-crystaline of HAp can be produced if $\mathrm{pH}$ of solution was more than 9, and $\mathrm{pH}$ also be able to influence the morphology of Hap synthesized [12].

\section{CONCLUSION}

The effect of $\mathrm{pH}$ on synthesis of hydroxyapatite from Geloina coaxans shell has been done by precipitation method. Geloina coaxans shells and several phosphate sources $\left(\mathrm{NH}_{4}\right)_{2} \mathrm{HPO}_{4}$ and $\mathrm{H}_{3} \mathrm{PO}_{4}$ were used as precursors on synthesis of HAp.The result proved that nano-HAp can be obtained successfully and shown that $\mathrm{pH}$ value was a significant parameter variable on synthesis HAp that can influence crystalinity and purity of HAp. Using Schererr equation, particle size of HAp powder of $\left(\mathrm{NH}_{4}\right)_{2} \mathrm{HPO}_{4}$ was 26,69 while $\mathrm{H}_{3} \mathrm{PO}_{4}$ was $40 \mathrm{~nm}$ respectively.

\section{REFERENCES}

[1] C. Srilakshmi and R. Saraf, "Ag-doped hydroxyapatite as efficient adsorbent for removal of Congo red dye from aqueous solution: Synthesis, kinetic and equilibrium adsorption isotherm analysis,” Microporous Mesoporous Mater., vol. 219, pp. 134-144, 2016.

[2] J. Reichert and J. G. P. Binner, “An evaluation of hydroxyapatite-based filters for removal of heavy metal ions from aqueous solutions,” J. Mater. Sci., vol. 31, no. 5, pp. 1231-1241, 1996.

[3] M. Zahouily, Y. Abrouki, B. Bahlaouan, A. Rayadh, and S. Sebti, "Hydroxyapatite: new efficient catalyst for the Michael addition,” Catal. Commun., vol. 4, no. 10, pp. 521-524, Oct. 2003.

[4] S. Sugiyama, T. Minami, H. Hayashi, M. Tanaka, N. Shigemoto, and J. B. Moffat, "Partial Oxidation of Methane to Carbon Oxides and Hydrogen on Hydroxyapatite: Enhanced Selectivity to Carbon Monoxide with Tetrachloromethane,” Energy \& Fuels, vol. 10, no. 3, pp. 828-830, Jan. 1996.

[5] S. Salman, S. Soundararajan, G. Safina, I. Satoh, and B. Danielsson, "Hydroxyapatite as a novel reversible in situ adsorption matrix for enzyme thermistor-based FIA,” Talanta, vol. 77, no. 2, pp. 490-493, Dec. 2008.

[6] Y. Qi, J. Shen, Q. Jiang, B. Jin, J. Chen, and X. Zhang, "The morphology control of hydroxyapatite microsphere at high pH values by hydrothermal method,” Adv. Powder Technol., vol. 26, no. 4, pp. 1041-1046, Jul. 2015.

[7] A. Shavandi, A. El-Din, A. Bekhit, A. Ali, and Z. Sun, "Synthesis of nano-hydroxyapatite (nHA) from waste mussel shells using a rapid microwave method,” Mater. Chem. Phys., vol. 149-150, pp. 607-616, 2015.

[8] S. Rujitanapanich, P. Kumpapan, and P. Wanjanoi, "Synthesis of Hydroxyapatite from Oyster Shell via Precipitation,” Energy Procedia, vol. 56, pp. 112-117, Jan. 2014.

[9] N. Viriya-Empikul, P. Krasae, B. Puttasawat, B. Yoosuk, N. Chollacoop, and K. Faungnawakij, "Waste shells of mollusk and egg as biodiesel production catalysts,” Bioresour. Technol., vol. 101, no. 10, pp. 3765-3767, May 2010.

[10] M. A. Ahmed, S. F. Mansour, S. I. El-Dek, S. M. Abd-Elwahab, and M. K. Ahmed, "Characterization and annealing performance of calcium phosphate nanoparticles synthesized by co-precipitation method," Ceram. Int., vol. 40, no. 8, pp. 12807-12820, Sep. 2014.

[11] Y. Zhang, J. Lu, J. Wang, S. Yang, and Y. Chen, "Synthesis of nanorod and needle-like hydroxyapatite crystal and role of pH adjustment,” J. Cryst. Growth, vol. 311, no. 23-24, pp. 4740-4746, Dec. 2009. 
Pepi Helza Yanti, et. al.,/ISoC Proceeding (33-38)

[12] J. Liu, X. Ye, H. Wang, M. Zhu, B. Wang, and H. Yan, "The influence of $\mathrm{pH}$ and temperature on the morphology of hydroxyapatite synthesized by hydrothermal method," Ceram. Int., vol. 29, no. 9, pp. 629-633, 2003. 